International Journal of Business and Management Review

Vol.4, No.10, pp.86-103, December 2016

Published by European Centre for Research Training and Development UK (www.eajournals.org)

\title{
CORPORATE SOCIAL RESPONSIBILITY IN NIGERIA: A CRITICAL REVIEW OF THE LITERATURE
}

\author{
Sunday C. Eze and Adenike O. Bello
}

Department of Business Studies, Landmark University, Kwara State

\begin{abstract}
The paper reviews existing literature on Corporate Social Responsibility (CSR) to ascertain the level of corporate social responsibility activities that will enhance the performance/profitability of businesses in Nigeria. It revealed that the success of an organization depends on the extent to which the organization is capable of managing its relationship with key groups, such as financial and stakeholders, but also customers, employees, and even communities or societies. Stakeholders must be considered in the decision making process of the organization. CSR is a concept that includes many different activities and actions which businesses have to involve themselves in for the purpose growth sustainability and growth of businesses. Businesses that voluntarily participates in local community development, such as providing the community with donations, assisting them with projects and sharing some of its profit with the community, helps to increase the business profitability in the long-run.
\end{abstract}

KEYWORDS: CSR, Nigeria, Literature, organisation, performance, Nigeria,

\section{INTRODUCTION}

The concept of Corporate Social Responsibility has been in existence for over 30 years and Academics and practitioners have been determined to establish and agree upon a definition for the concept. Corporate Social Responsibility (CSR) as a concept has no consensus definition. However, various authors have defined it nevertheless. These definitions vary as per upbringing, Interest, Experiences, as well as morals of the Author. Nkanga (2007) posited that corporate social responsibility involves the commitment shown by companies to contribute to the economic and social development of a local community and the society at large. Kotler and Lee (2005) essentially see CSR in the same way. Scholars have defined CSR as 'a commitment to improve community well-being through discretionary business practices and contributions of corporate resources'.Many organizations such as banks and some manufacturing companies in Nigeria are driven by the need to make more and more profits and that is the sole aim of every business. In a bid to meet this target, some companies do not adequately respond to the needs of host communities, employees' welfare (cheap labor often preferred), environmental protection and community development amongst environmental . The importance of social responsibility is to achieve balance between corporate profits which contribute to the development and to the welfare of the community through their interest in social and environmental issues and through the preservation of resources as well as the potential of the community in which they operate (Appelbam et al 2009).

Some scholars argue that companies can —"do well by doing good" (Godfrey, 2005; Margolis et al., 2007; Porter and Kramer, 2011) based on the assumption that meeting the needs of other 
stakeholders - e.g. employees through investment in training - directly creates value for shareholders (Freeman et al., 2010, Porter and Kramer, 2011). It is also based on the assumption that by not meeting the needs of other stakeholders, companies can destroy shareholder value because of consumer boycotts (e.g., Sen et al., 2001), the inability to hire the most talented people (e.g., Greening and Turban 2000), and by paying potentially punitive fines to governments. On the other hand, other scholars argue that adopting environmental and social policies can destroy shareholder wealth (e.g., Friedman 1970; Clotfelter 1985; Navarro 1988; Galaskiewicz 1997). In its simplest form, their argument is that sustainability may simply be a type of agency cost: managers receive private benefits from embedding environmental and social policies in the company' strategy, but doing so has negative financial implications for the organization (Baloti and Hanks 1999; Brown et al., 2006).

Clearly, from the foregoing, the importance of the role of corporates in society and its social responsibility show an indication to the extent of their interaction with the community in which they operate. Research has shown that corporate social responsibility can increase profitability, sustainability, increased patronage, integrity and reputation of any business that includes it in its policy. Some critics according to Carpenter, et al. (2010) have argued that corporate social responsibility as implemented by some organizations is mere facade. It is widely believed by many that corporate social responsibility efforts are mere campaigns by organizations to promote corporate brands. Many Nigerians are ignorant of corporate social responsibility; hence, whenever an organization does something 'supposedly big' for the society, such a company and its management are eulogized for being caring and philanthropic.

A lot of companies and their managers have ignored the problems created by corporate firms to their host communities. These problems pose a lot of danger and sometimes make life difficult for these communities. The privilege given to organizations to operate in the society stems from the act that society believes that there is a mutual interdependency that should exist between them, that is, the organization and the society. In the last years, the call for increased social responsibility, by governments, investors and corporations, was distinctive and urgent due to the global crises that took a central role, financial market breakdowns, severe economic declines and food shortages required immediate responses all over the world. It seemed that climate change finally received due attention, with growing recognition of critical consequences without a significant change in the course. Therefore, there is a need to examine the problems and prospects of corporate social responsibility in Nigeria.

\section{LITERATURE REVIEW}

Over the years, the conception of corporate social responsibility (CSR) has grown rapidly in importance and significance. It has been a topic of considerable debate, commentary, theory building and research. In spite of the ongoing deliberations as to what it means and what it embraces, it has developed and evolved in both academic and practitioner communities around the world. The motion that business enterprises have some responsibilities to society beyond that of making profits for the shareholders has been around for centuries. Today, in newspapers, magazines or journals there is often some discussion of the issue, some recent innovative example of what businesses are thinking or doing about CSR, or some new conference seminar 
or even workshops that is being held. Specific journals, news magazines, books, dictionaries, encyclopedias, websites, discussion lists and blogs treat the concept on a regular basis. The business community has formed its own organizations specializing in the topic. Business for Social Responsibility (BSR), for example, is a business association founded in 1992 to provide corporations with expertise on the subject and an opportunity for business executives to advance the field and learn from one another. There has been an explosion of interest in CSR in the European Union and around the world.

The following characteristics are common when dealing with Corporate Social Responsibility as put forward by The European Foundation for Quality Management (EFQM, 2007):

- Meeting the needs of current stakeholders without compromising the ability of future generations to meet their own demand.

- Embracing corporate social responsibility voluntarily, rather than as legal requirement, because it is seen to be in the long-term interests of the organization.

- Incorporating social, environmental and economic policies in day-to-day business.

- Accepting corporate social responsibility as a core activity that is embedded into an organization's management strategy.

The European Foundation for Quality Management (EFQM, 2007) highlighted three particular dimensions of corporate social responsibility with similarly particular cases specific to every region of the dimensions. They are as follows:

\section{Economic Responsibility}

Integrity, corporate governance, economic advancement of the community, straightforwardness, avoidance of pay offs and defilement, installments to national and local authority, utilization of neighborhood providers, contracting neighborhood workers and similar or nearby territories. It underlines the necessities for a business working inside a community to perform in a way obvious with expanding compensation per offer; be based on being helpful as would be reasonable; keep up a solid powerful position; keep up an unpredictable state of working adequacy; and that a lucrative firm be depicted as one that is reliably productive (Carroll, 1991:40).Regardless, Barnett (2007) battles that over the top financial execution is not in light of a legitimate sympathy toward allies.

\section{Ethical Responsibilities}

Moral commitments are benchmarks which the overall population foresees that the business will watch like not relying upon putting away and different misbehaviors. While financially related and truthful commitments join moral guidelines about certainty and esteem; moral duties hide exercises and practices that are exemplary or prohibited by the general populace, however not incorporated into law. Moral duties recommend significant manager's qualities about incredible and terrible business direct or lead. Morals or qualities are changing and go 
under the watchful eye of the foundation of law. Basically, morals are the focal reason behind the making of laws or controls. Also, great duties handle society making qualities and rules which an organization are relied on to meet. Now and then, such values and models may require a higher standard of execution than that required by law. Carroll's ethical part advocates the fundamentals for a firm to: perform in a path solid with societal longings and awesome principles; see and respect new or making moral/moral measures understood by society; and keep moral gages from being exchanged off to fulfill corporate targets (Carroll, 1991:41).I

\section{Environmental Responsibility}

Precautionary measures to avoid or diminish unfavorable impacts encouragement for endeavors, empowering better environmental duty, creating and distributing eco-friendly innovations and similar regions.Lohman and Steinholtz (2004) viewed the corporate social responsibility as a blend of three separate motivation, in particular Corporate Sustainability, Accountability and Governance. The creators inferred "Corporate Sustainability" from the United Nation meeting in Rio de Janeiro in 1992 and the Agenda 21. In the UN meeting, Corporate Sustainability was expressed to be the means by which to report and adjust the social, financial and environmental regions on the planet so that the long haul survival is not jeopardized.

Corporate Accountability focused on the honesty of the organization and this was utilized as a part of conditions where contemplations are said to be in regards to the ability of the organization to succeed (Lohman and Steinholtz, 2004). Corporate Governance was utilized as a part of the dialog about how an organization is being operated. It manages limpidity and over the long haul unwavering quality (Lohman and Steinholtz, 2004) Corporate Governance significance emerges in present day partnerships because of the partition of administration and ownership control in the organizations. The interests of shareholders are clashing with the interests of managers. The foremost principal issue is reflected in the management and heading of related issues because of the differential interests of organization's partners. There is not a solitary meaning of corporate governance rather it may be seen from various angles. OECD in 1999 characterized corporate governance as "Corporate governance is the framework by which business partnerships are coordinated and controlled. The corporate governance structure indicates the appropriation of rights and duties among various members in the organization, for example, the board, managers, shareholders and other members, and spells out the tenets and methods for settling choices on corporate issues. By doing this, it likewise gives the structure through which the organization goals are set, and the method for achieving those destinations and checking execution." Oman (2001) characterized corporate governance as a term refers to the private and open foundations that incorporate laws, directions and the business practices which oversees the relationship between the corporate governance and the partners. Bowen (1953) underscored that business in any general public needs to assume liability, for each choice that is made, each move that is made, must be seen in the light of that sort of responsibility. Social Responsibility requires business organizations to adjust the advantages to be picked up against the expenses of accomplishing those advantages. There is the general conviction that both business and society pick up when firms effectively endeavor to be socially dependable. While business organizations pick up in improved reputation, society picks up from the social undertakings executed by the business organizations. 


\section{Carroll's pyramid of corporate social responsibility}

Yet no single by and large recognized definition had been credited to the subject CSR, which had progressed since 1970s, Archie B. Carroll had said that "there had been cash related, moral, honest to goodness and liberal perspective to the subject". Accordingly, a champion amongst the most utilized and referred to model is the Carroll's pyramid of CSR, 1991. Carroll considers CSR to be encased in a way that the whole degree of business duties is understood. These four duties can be showed up as a pyramid. The fiscal part is about the commitment to advantage which serves as the base for substitute sections of the Pyramid. As to the legitimate viewpoint, society anticipates that associations will conform to the laws and directions. Moral commitments are about how society envisions that affiliation will get a handle on qualities and gauges paying little mind to the way that the and models may constitute a higher standard of execution than required by law. Altruistic obligations are those activities that are normal from an organization as a decent corporate subject.

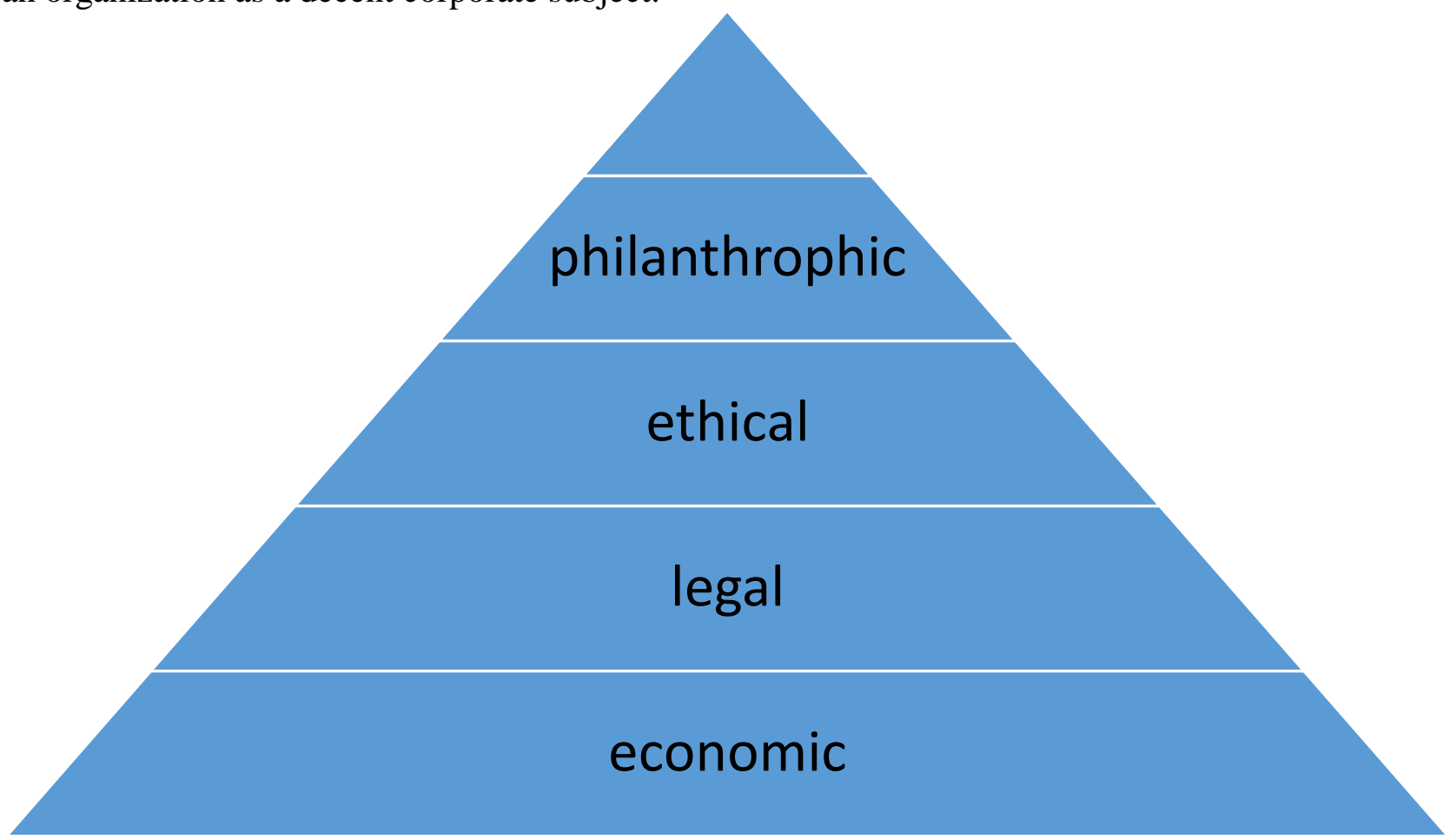

Source: Onuoha, 2010

\section{Social responsibility to stakeholders}

An organization ought to satisfy its social obligations to the accompanying partners for it to accomplish its set destinations.

\section{Customers}

Purchasers are those individuals and associations that purchase the association's items and administrations. They thusly, trade assets, as a rule in type of cash. The achievement or disappointment of any association is controlled by their support. They decide offering strategies that ought to be utilized by the association in showcasing the association's items or administrations in the business sector. Potential clients and economic situations are broken down by promoting supervisors. That is the reason they guarantee that their item quality is top 
notch, promptly accessible at appropriation and costs are less with the goal that contenders won't have an edge over them in the business sector.

\section{Shareholders}

Organizations are to defend the shareholders' speculation and endeavor endeavors to give a sensible profit for their venture. The essential enthusiasm of shareholders is the manner by which the business is fighting. The representing structure of any venture permits shareholders to impact an organization by practicing their voting rights. Hence organizations ought to guarantee safe ventures through great and sound administration.

\section{Employees}

Workers are the most essential part of an association. Their obligations towards workers incorporate; convenient installment, hygienic environment, great and unbiased conduct and urging them to join in administrative choices. Favorable workplaces i.e. make accessible advanced working instruments and hardware, ventilated workplaces, great base, wellbeing and security gear at the work environment and so forth in light of the fact that the representatives of a business association render administrations. They likewise include in the generation of products or administrations which the business association offer. In this way, chiefs should dependably try to get the right gauge of laborers in the workforce.

\section{Government/State}

From the accessible benefit, the state is qualified for a specific offer according to the wage charge laws. Most extreme straightforwardness must be applied in regards to the benefit \&loss account and the asset report. Being a dependable corporate substance or native, organizations ought to guarantee that they agree to the laws and directions endorsed by administrative powers. Help government in financing and advancing social exercises, for example, supporting games programs, commitments towards fighting illnesses e.g. Helps, and so on since the Nigerian government has indicated enthusiasm for the private area of the economy and this they do by controlling the exercises of every single profitable association to open intrigue and strengthening laws and setting up offices or administrative bodies to guarantee that these laws are held fast to. They have gone about as a defender of business through keeping up local peace and security.

\section{The open}

Organizations socially mindful to people in general, as a rule, and individuals from the group in which they are arranged, specifically, in the accompanying ways:

- Development of the earth through procurement of fundamental offices like great drinking water, gifts to advancement affiliations, conveying keeping money administrations to the provincial ranges, indigenous loaning, and so forth.

- Creation and support of business chances to qualified individuals from the group. This energizes dedication, duty and participation from the group.

- Participation in group exercises, for example, gifts to group to festivities, granting grant to meriting individuals from the group, and so forth., and 
- Using the aptitudes of workers to create magnanimous products and administrations.

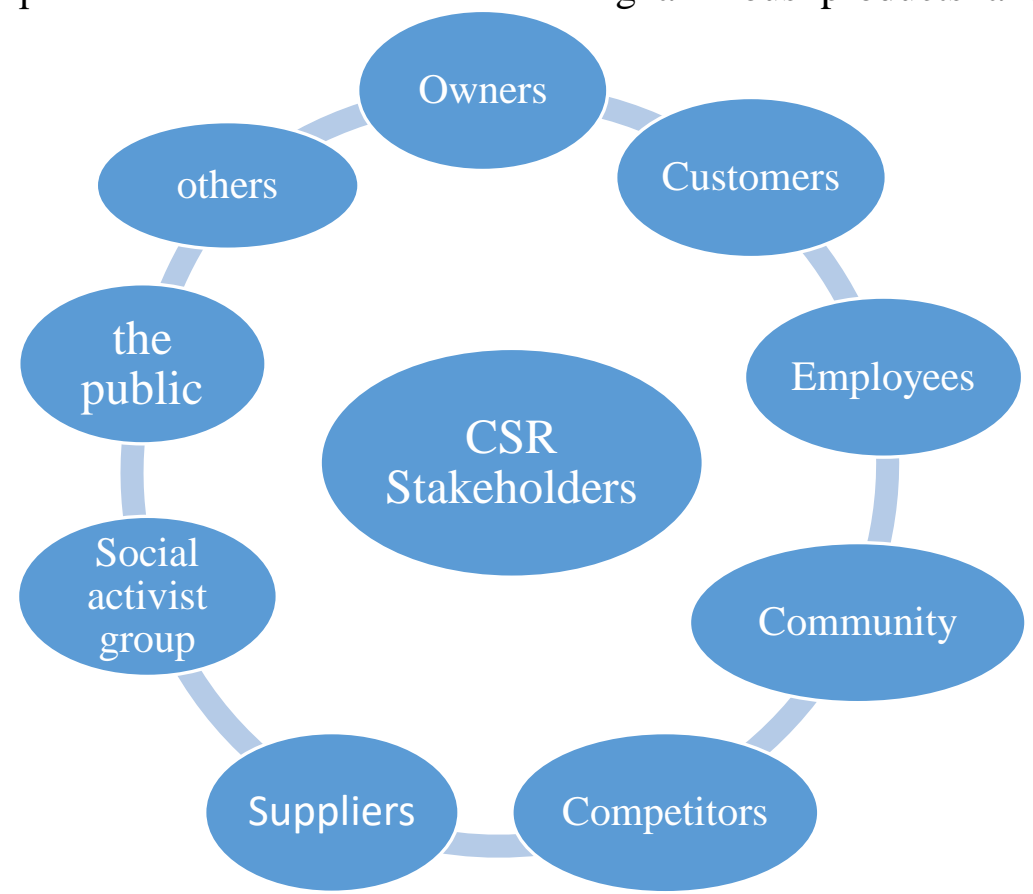

Source: Adjusted from Carroll A. B (1991, 10) the Pyramid of Corporate Social Responsibility:Toward the Moral Management of Organizational Stakeholders

\section{Attributes that drives corporate social responsibilities that drives corporate social obligations}

\section{Defending open picture}

On the off chance that organizations act disgracefully, they can be got at through the court of all inclusive general evaluation. The essential CSR exercises were a response to open weight and media presentation of poor affiliation conduct. CSR should show that affiliations were fit for making some sort of leap forward. Prof. Michael Porter of the Harvard Business School fights that CSR is all watched exertion, a PR amusements in which affiliations essentially respond to manage the faultfinders and the weight from activists.

\section{Attracting speculators}

Organizations that proactively interface with down to earth progression inspiration and its supporter in the endeavor world should make reinforce, premium and cognizance among monetary masters. This will finally credit a premium to share cost. CSR makes organizations engaging both standard examiners and to the rapidly creating moral wander part.

Various budgetary masters now assume that social and biological threat organization upgrades an association's decently assessed worth in the whole deal.

\section{Consent to work}

CSR has, for the most part transform into a basic section in associations' push to get underwriting for exercises passing on immense political and social perils.

\section{Campaigning against directions}

One of the key parts of CSR is to empower further deregulations by demonstrating the dedication of business in great and feasible exercises and to display that multi--accomplice 
trade with basic culture thwarts the prerequisite for confining control" (David Miller, Sterling Media Research Institute). I assume that associations' purposeful measures can upgrade private-part lead. Regardless, purposeful development is not a feasible option for control and there is confirmation that associations that grasp intentional approaches to manage meeting social and common gages are furthermore required in contradicting external course, especially by government.

\section{Corporate Social Responsibility and Organizational Performance and Profitability}

Organizations around the world are battling with another part, which is to address the issues of the present era without compromising the capacity of the succeeding eras to address their own particular issues. Organizations are being called upon to assume liability for the ways their operations affect social orders and the indigenous habitat. They are likewise being implored to display the incorporation from social and environment worries in business operations and in collaborations shareholders. (Van Marrewijk and Verre, 2003).

Organizations have set up a variety of systems for managing the meeting of societal needs, the regular environment, and acclimating business necessities with respect to how significantly and how well they are joining social responsibility approaches into both methodology and every day routines all inclusive.

Little (2006) continued that corporate social responsibility activities can prompt the developments using social, environmental, or supportability drivers to make new products and services.

The topic of environmental and social responsibility shows up in various political and authoritative archives and is picking up ever-more noteworthy significance at the worldwide level. Today, corporate pioneers confront a dynamic and testing errand in endeavoring to apply societal moral models to dependable business practices.

In any case, there is a lot of vagueness and instability about what corporate social responsibility truly implies and additionally what drives a business to seek after it. Whatever are the inspirations driving corporate social responsibility speculations, it is likewise translated as the idea of triple main concern ("People, Planet, Profit") which catches an extended range of qualities and criteria for measuring organizational achievement; financial, environmental and social. While business morals and corporate management join to create the way to accomplish hierarchical greatness, the genuine test is the point at which this magnificence is changed over into business manageability and here, corporate social responsibility assumes a noteworthy part.

Different perspectives have been offered to clarify the significance or generally of corporate social duty (corporate social responsibility) in business movement. As far as it matters for them, neoclassical financial analysts propel that the organizations ought to commit their energies to providing products and enterprises to their clients, they ought to minimize costs and amplify profits; and this ought to, obviously, happen inside the laws and guidelines/controls of the land (Carroll, 1979; Jamali, 2006; Jamali and Mirshak, 2007; Quazi and O'Brien, 2000). In reality, a few defenders of this perspective venture to contend that corporate social responsibility is not just a redirection from the principle business of wealth creation, along these lines serving to 
International Journal of Business and Management Review

Vol.4, No.10, pp.86-103, December 2016

Published by European Centre for Research Training and Development UK (www.eajournals.org)

limit rivalry, but at the same time is a monetary (cost) inconvenience on the firm (Friedman, 2008).

Speculations on the association between corporate social performance and firm profitability depend on harmony resource evaluating models and on the effective market theory (Guenster et al., 2005). It predicts three conceivable relations. One way of thinking proposes a impartial connection. It accept that the hazard connected with consistence with Corporate Social Responsibility is not estimated, hence all organizations, corporate social responsibility going along and non-corporate social responsibility going along, have a similar rate of expected return and face a similar cost of value capital (Hamilton et al., 2003).

This thinking is in accordance with standard money related hypothesis (risk-return worldview) where just hazard variables are estimated in the market. Then again, if the hazard related to Corporate Social Responsibility consistence is (effectively) estimated by the market, a similar hazard return worldview would infer a negative connection between corporate social performance and financial performance. As set forward by Shane and Spicer (1983), firms which effectively represent the corporate social responsibility risk component are viewed as less dangerous ventures (in respect to the organizations that disregard it). Thus, on a hazard balanced premise, their normal returns are anticipated to be lower.

At long last, the third view proposes that the consistence with Corporate Social Responsibility standards is not productively evaluated by market members. A positive (negative) connection takes after relying upon the indication of the wastefulness. For instance, Hamilton et al. (2003) contend that, if an adequately extensive number of financial specialists disparage (overestimate) the likelihood that antagonistic occasions identified with Corporate Social Responsibility issues may influence organizations not consenting to the corporate social responsibility standards, then their stocks will give lower (higher) hazard balanced return than socially dependable organizations stocks.

Since the response to the question whether the hazard related to Corporate Social Responsibility issues is (accurately) valued by the market can't be given on hypothetical grounds alone, it is financial specialists' view of the pertinence of the Corporate Social Responsibility rule that checks at last. On the off chance that investors believe that organizations executing the Corporate Social Responsibility principles are asset inefficient, they would decide a negative profit premium for these organizations stocks. Unexpectedly, if corporate social responsibility conduct of organizations is in accordance with financial specialists' convictions, they would decide a positive return premium for these organizations stocks (Ullman, 2005).

\section{Corporate Social Responsibility, Customers' Patronage and Brand Loyalty}

Cornell and Shapiro (2007) examines on the relationship between corporate social responsibility and support and brand dedication appeared there is a positive connection. The creators' perspective for positive connection between corporate social responsibility and support and customer loyalty recommended that as an organization's express expenses are inverse of the shrouded expenses of partners, in this manner, this perspective is proposed from 
the points of view of evading expense to significant stakeholders and considering the fulfillment of their desires.

Cornell and Shapiro (2007) also instigated that dedication to corporate social responsibility would bring about augmented expenses to competitiveness and conceal the expenses of stakeholder. Their argument was important and sensible, as great organizations with workers, providers, and clients are fundamental for the survival of an organization.

Bowman and Haire (2008) called attention to a few shareholders to see corporate social responsibility as a typical management know-how, to be specific, corporate social responsibility is an image of reputation, and the organization reputation will be enhanced by activities to bolster the community, bringing about positive impact on sales. Consequently, when an organization increases its cost by enhancing corporate social responsibility keeping in mind the end goal to increased competitive advantage, such corporate social responsibility exercises can upgrade organization reputation, accordingly, over the long haul, patronage and brand dependability can be enhanced, by yielding the fleeting support and reliability of the customers.

According to Simpson and Kohers (2002), the relationship between corporate social responsibility and support and brand loyalty has been given tremendous consideration among researchers. Simpson and Kohers (2002) thinks about the linkage between corporate social responsibility and support and brand loyalty demonstrated negative corroletion.

Simpson and Kohers (2002) perspective for negative connection between corporate social responsibility and support and brand loyalty proposed that the satisfaction of corporate social responsibility will convey the drawbacks of the organization strategies or need to shoulder extra expenses. The author further emphasized that when undertaking corporate social responsibility exercises, extra expenses will bring about little gain if measured in financial interests. While ignoring a few shareholders, for example, workers or the environment, result in a lower corporate social responsibility for the organization, the support and brand loyalty might be moved forward.

\section{Problems of Corporate Social Responsibility}

\section{Problems}

In spite of the glaring insufficiency in government organization arrangements, some business organizations claimed ignorance and do nothing while those making the best choice are not supported by the government as to encourage others to yield. Militating issues on corporate social responsibility incorporate uncertainty coming about because of tenacious savage clashes, unemployment, religion intolerance, ethnics' disturbance and various emergencies; corruption, poor attention to objectives achievement, poor direction, particularly corrupting condition of infrastructural improvement and upkeep and of cause natural disasters, for example, fire outbreaks, droughts and floods. 
Chiejina (2011) reported that numerous variables represent the clear disregard of corporate social responsibilities by Nigerian organizations for the advancement of the country. Such difficulties among others include:

1. The need for expertise in management style. Numerous Nigerian supervisors don't see social responsibility as one of the key elements of management. The managers need social abilities or skills to manage and deal with social matters.

2. Many Nigerian organizations are little in size and their financial capabilities impedes the thought of social responsibility as a task that must be truly considered. A portion of the other substantial organizations are owned by foreign firms whose fundamental pre-occupation is profit maximization. Some of these organizations see social duty as a patriotic motion best embraced by indigenous professionals or organizations to help their nation.

3. Involvement in social exercises could unfavorably influence the financial wellbeing of a business venture. It is in spite of the fundamental capacity of the business. For instance business endeavor might need to augment profit or augment market share of the overall industry which is the target of the organization.

Numerous organizations include themselves in social exercises on account of the tax exceptions or the income spent on rare purposes. Corporate Social Responsibility process is "routinely being mishandled due to the scramble for augmenting profits. From oil multinationals, media transmission mammoths, to the banking sector, it has ended up en vogue to take part in profoundly publicized benevolent and charitable ventures as a demonstration of corporate social responsibility to plicate the manhandled public. Also, in more ways than one, many approaches to deal with corporate social obligation set organizations against society, consequently accentuating the cost and impediments of consistence with remotely forced social and environmental norms (Chiejina, 2011).

\section{Prospects}

Corporate Social Responsibility makes better mindfulness and acknowledgment of organization's product that support a greater part of people to consistently disparaging concerned organizations' and contribute essentially to encourage their development and improvement specifically and the national economy by and large. No clients, no business. Nigeria's huge populace of more than 150 million people makes her appealing to outside foreign investors. Social responsibilities by their inclination don't add to a businessman's benefit in the short run yet profit the larger society over the long haul. Being an individual from the larger society, the businessman is required to profit over the long haul. In the event that each specialist acts socially dependably, the general public will be a bigger place and will gain speedier ground to grow. To legitimize the contentions for social responsibility, Salawu (2007) expressed that an organization couldn't exist in isolation from the general public in which it is found. No business can overlook the environment in which it works. In addition, accomplishment of organizations may depend, to a large degree, upon their public image.

Salawu (2007) likewise reported that Corporate Social Responsibility offers a "two-way stream of advantage to the organizations. From one viewpoint, it animates creative business and mechanical activities which would open up new market paths for organization operations. 
Moreover, it will concentrate on the possibility of touching new market zones. Then again, it will give a clearer societal reputation and socially dependable personality to organizations and their workers over the long haul. Corporate social duty empowers organization and people or group to add to the prosperity of recipients and the general public.

\section{Corporate Social Responsibility (CSR) In Nigeria}

With regards to Nigeria and the advancement of corporate social responsibility, Nigeria has been a party to a few worldwide human rights arrangements. The legislature of Nigeria is one of the governments together with Azerbaijan and Ghana, Kyrgyzstan who have focused on the UK-led Extractive Industries Transparency Initiative, where they have focused on making open every one of their incomes for oil, gas and mining.

Expanding on the United Nations statements, traditions and endeavors of constituents particularly the International Labor association, the ISO has proceeded with a procedure towards a blended approach under the initiative of both the Swedish Standard Institute and the Brazilian Association of Technical Standards. This procedure has active participation of Nigeria where the National Mirror Committee on Social Responsibility is attempting to contribute towards the finish of ISO 26000 by 2008 . The point is to urge deliberate duty to social responsibility and will prompt to basic direction on ideas, definition and techniques for assessment.

The Nigerian government has additionally through its NEEDS strategy (Nigerian National Planning Commission 2004) set the context by characterizing the private sector part as by expressing that "the private sector will be required to end up more proactive in making profitable employments, upgrading efficiency, and enhancing the personal satisfaction. It is additionally expected that would be socially dependable, by putting resources into the corporate and social improvement of Nigeria."

Also, a Global Compact system was authoritatively propelled in Nigeria during the twelfth Annual Nigerian Economic Summit in Abuja in 2006 where some Nigerian organizations have officially marked on to the Global Compact. The Nigerian oil sector is overwhelmed by multinational organizations. To make up for the government's administration disappointments and to ensure their own business advantages, the organizations regularly take part in corporate social responsibility. The historical backdrop of formalized corporate social responsibility in Nigeria can be followed back to the corporate social responsibility practices in the oil and gas multinationals with the concentration on curing the impacts of their extraction exercises on the nearby communities. The organizations give pipe-borne waters, health facilities and schools. Commonly these activities are specially appointed and not generally sustained (Amaeshi et al., 2006). As per (Amaeshi et al., 2006) it creates the impression that Nigerian organizations are occupied with one corporate social responsibility movement or the other. In any case, 85 percent of the respondents said that there is an attention to corporate social responsibility in Nigeria yet without noteworthy activities, while 7.7 percent either claimed there is no mindfulness with critical activities, individually. 


\section{CONCLUSION}

In its stronger form, the concept of Corporate Social Responsibility (CSR) asserts that corporations have an obligation to consider the interests of customers, employees, shareholders, host communities, as well as the ecological "footprint" in all aspects of their operations, there is need to battle with this wrong notion and orientation to accepting CSR programs as a necessity and an unavoidable option to organizations knowing that they are not operating in a vacuum but within the society and as such should reciprocate by meeting some of her expectations. Another lacking area on corporate social responsibility is that most of the studies on corporate social responsibility were conducted on nations with developed economies and their findings were found out not to be applicable to some developing nation's economy like the Nigeria. Therefore, the study examined the problems and prospects of corporate social responsibilities in Nigeria with emphasis on SMEs . It is ironic that these organizations take resources from the external environment and it is only natural to give back what has been exploited. Unfortunately, this anomaly is a norm in this part of the globe and this cankerworm can only be ameliorated through research and awareness emphasizing the importance of corporate social responsibility in our society.

Relationship with the community is more substantial in the implementation of corporate social responsibility, the elevation of corporate image and reputation influenced the adoption of corporate social responsibility practices and companies have adequate labour force to implement and oversee the corporate social responsibility initiatives.

- Deficiency of knowledge is the main problem related to the growth of corporate social responsibility.

- Enhancing corporate reputation and image are the major advantages for the adoption of corporate social responsibility.

- The state of the Nigerian economy does not encourage the adoption of corporate social responsibility practices in their companies very much at this time.

- Most companies' current corporate social responsibility activities are good enough and their corporate social responsibility initiatives are helping in creating brand awareness.

\section{REFERENCES}

Achua, J. K. (2008) Corporate Social responsibility in Nigerian Banking system. Society and Business Review Vol. 3 No.1, pp2-18

Amaeshi, K. M., Adi, A. B. C., Ogbechie, C. and Amao, O. O. (2006) Corporate Social Responsibility in Nigeria: Western Mimicry or Indigenous Influences? Available at: SSRN: http:// HYPERLINK "http://ssrn.com/abstract=896500"ssrn.com/abstract

Bendixen, E. W., and Abratt, C. L. (2007) Customer satisfaction and shareholder value. Journal of Marketing: 172-185.

Bhattacharya, C. B. and Sen, S. (2004) Doing Better at Doing Good: When, Why, and How Consumers Respond to Corporate Social Initiatives. California Management Review,47 (1),9-24. 
International Journal of Business and Management Review

Vol.4, No.10, pp.86-103, December 2016

Published by European Centre for Research Training and Development UK (www.eajournals.org)

Black, D. (1989) Managing organizations in Africa, Berlin and New York: Walter de Gruyter, pp.169-171.

Bowman E. H. and Haire M. (2008) A strategic posture toward corporate social responsibility, United States, Los Angeles: California Manage. Rev. 18(2), 49-58.

Bromley, T. J. (2001) The company and the product corporate associations and consumer product responses. The Journal of Marketing 61(1): 68-84.

Business Day (2003) Cadbury Nigeria Plc. Rolls Out more Corporate Social Responsibility Projects in 20th century. PP 12

Carroll, A. B. (1979) A Three-dimensional Conceptual Model of Corporate Performance. Academy of Management Review, 4, (4), pp. 497-505.

Carroll A. B. and Buchholtz, R. (2003) The pyramid of corporate social responsibility: towards the moral management of organizational stakeholders, Business Horizon, 34 (4), pp 3948.

Chiejina A. (2011) How to Deploy CRS to Benefit Host Communities, Business Day, May 10. P19.

Charles, P. (2010) Companies look at corporate social responsibility initiatives for branding slump. http://www.livemint.com/2009/02/08111815/Companies-look-at-corporate social responsibility-initiati.html (accessed 24 December, 2012).

Chi-Shiun Lai, Ettlie, J. E. and A. H. Rubenstein (2010) "Firm size and product innovation." Journal of Product Innovation Management 4(2), 89-108.

Cornell, S. and Shapiro, M. (2007) Understanding the Influence of corporate social responsibility on Corporate Identity, Image, and Firm Performance. Management Decision, 48, (10),1469-1492.

Carpenter, T. Andrew,A.D., Da-silva, B. (2010): Corporate Social Responsibility in India- An Empirical Research. [Online] Available: http://www.EzineArticles.com

Davis, T. (1960). Corporate Social Responsibility and organizational Profitability". J. Econ. Soc. Res. 3(1):113-124.

Davis, K. (1960) Corporate Social Responsibility and organizational Profitability. J. Econ. Soc. Res. 3(1):113-124.

Dean, D. H. (2008) Consumer perception of corporate donations effects of company reputation for social responsibility and type of donation. Journal of Advertising 32(4): 91-102.

Detomasi, D. A. (2008) The political roots of corporate social responsibility. Journal of Business Ethics, 82, 807-819.

European Foundation for Quality Management (EFQM, 2007) EFQM internal report. http://www.efqm.com.my/aboutdigi/ doc (accessed 22 December, 2012).

Eells, S and Walton, T (1961). The path to corporate responsibility, HBR, December 2004, pp. 125-132.

Fombrun, T.M (2006) Shareholder value, stakeholder management, and social issues: What's the bottom line?" Strategic Management Journal, 22 (2): 125-139.

Friedman, (2008) The social responsibility of business in to increase its profits. New York Times Magazines, 13 Sept., 32-33.

Frooman, J. D. (1997) "Strategic philanthropy: responding to negative portrayals of corporate social responsibility." Corporate Reputation Review 3(2), 124-136.

Garriga F. and Mele, S. (2004) Corporate Social responsibility as Risk Management: A model for Multinationals. Social Responsibility Initiative Working Paper, No.10. Cambridge MA. John F. Kennedy School of Government, Harvard University. 
Gray, R. and Balmer, D. (1998) Social and Environmental. Disclosure and Corporate Characteristics: A Research note and Extension. Journal of Business Finance and Accounting, 28 (3 \&4), pp.327-356.

Guenster, H., Rettab, E., Brik, P. and Mellahi, T. (2005) Corporate social responsibility - a PR invention?, Corporate Communication. An International Journal, Vol. 6 (1), pp. 18-23.

Hamilton, D., Griffin, J.J. and Mahon, J.F. (2003) "The Corporate Social Performance and Corporate Financial Performance Debate: Twenty-Five Years of Incomparable Research." Business and Society. 36: pp 5-31.

Herremans, T., Collier, T., De Man, F. and Kahn, T. (2003) Corporate social responsibility and its impact on corporate reputation, Brand Strategy (Sept), Issue 195, p. 40-41.

Matten, R. K. and Moon, N. S. (2004) An analysis of linkage between economic value added and corporate social responsibility", Management Decision, 46(9): 1437-1443.

McWilliams, A. and Siegel, D. (2000). Research notes and communications. Corporate social responsibility and financial performance: correlation or misspecification? Strategic Management Journal, 21 (1), pp 603-9.

Miles, D. J. (1987) "Corporate social performance revisited." Academy of management review: 691-718.

Nkanga, E. (2007). Nigeria: Telecom Operators and Corporate Social Responsibility. This Day, 31st Jan, 2007.www.google.adservices.com.

Onwuegbuchi, D.K. (2004). "The relationship Between Perceptions of corporate citizenship and Organizational Commitment." Business and society, 43(3), 296-319, Sage Publications.

Porter, R. and Cramer, G. (2002) Social capital in firm-stakeholder networks: A corporate role in community development. Journal of Corporate Citizenship, 26 (1), 121-134.

Quazi, E. and O'Brien, T. (2008) Evaluate Corporate Social Responsibility. Disclosure Annual Report Companies in Multifarious Group of Industry Members of Jakarta Stock Exchange, Indonesia. Social Responsibility Journal, 4(3) Emerald Group Publishing Ltd.

Salawu R. O. (2007) "Corporate Social Responsibilities, Nigeria, Onitsha: Africana FEP Limited Evidence from oil companies in Nigeria”. Nig. J. Bus. Soc Sc; 1(1), 31-42.

Secchi, D. (2007) Utilitarian, managerial and relational theories of corporate social responsibility. International Journal of Management Reviews, 9, (4), 347-373.

Shane L. and Spicer D. (1983) "The corporate social-financial performance relationship." Bus. Soc. 36: pp 419-429

Simpson, W. G. and Kohers, T. (2002) "The Link between Corporate Social and Financial Performance: Evidence from the Banking Industry," J. Bus. Ethics. 35, 97-109

Singer, J. D. H. (1970) "An empirical examination of the relationship between corporate social responsibility and profitability." Academy of Management Journal, 28 (2), 446-463.

Wartick, A. (1992) Trend performance in credit financing of rural business activities in Nigeria: A case study of community banks in Ibadan, Oyo State. International Journal of Agriculture and Rural Development, 7 (1): 50-60.

Whetten, S.A., and Mackey, B. G. (2002) "The corporation social performance - financial performance Link". Strategic Management. Journal. 18 (4), 303-319

Williams, T. and Barrett, P. (2000) "Making Corporate Social Responsibility (corporate social responsibility) Operable: How Companies Translate Stakeholder Dialogue into Practice.” Business and Society Review, 111 (2), pp 137-163.

Achua, J. K. (2008) Corporate Social responsibility in Nigerian Banking system. Society and Business Review Vol. 3 No.1 Emerald Group Publishing Limited. 
Published by European Centre for Research Training and Development UK (www.eajournals.org)

Amaeshi, K. M., Adi, A. B. C., Ogbechie, C. and Amao, O. O. (2006) Corporate Social Responsibility in Nigeria: Western Mimicry Or Indigenous Influences? Available at: SSRN: http:// HYPERLINK "http://ssrn.com/abstract=896500"ssrn.com/abstract

Bendixen, E. W., and Abratt, C. L. (2007) Customer satisfaction and shareholder value. Journal of Marketing: 172-185.

Bhattacharya, C. B. and Sen, S. (2004) Doing Better at Doing Good: When, Why, and How Consumers Respond to Corporate Social Initiatives. California Management Review, Vol. 47 No. 1, pp. 9-24.

Black, D. (1989) Managing organizations in Africa, Berlin and New York: Walter de Gruyter, pp.169-171.

Bowman E. H. and Haire M. (2008) A strategic posture toward corporate social responsibility, United States, Los Angeles: California Manage. Rev. 18(2): pp 49-58.

Bromley, T. J. (2001) The company and the product corporate associations and consumer product responses. The Journal of Marketing 61(1): 68-84.

Business Day (2003) Cadbury Nigeria Plc. Rolls Out more Corporate Social Responsibility Projects in 20th century. PP 12

Bhattacharya, C.B., Sen, S. \& Korschun D.( 2008)

Carroll, A. B. (1979) A Three-dimensional Conceptual Model of Corporate Performance. Academy of Management Review, Vol. 4, No. 4, pp. 497-505.

Carroll A. B. and Buchholtz, R. (2003) The pyramid of corporate social responsibility: towards the moral management of organizational stakeholders, Business Horizon, Vol. 34 No. 4, pp 39-48.

Chiejina A. (2011) How to Deploy CRS to Benefit Host Communities, Business Day, May 10. P19.

Charles, P. (2010) Companies look at corporate social responsibility initiatives for branding slump. http://www.livemint.com/2009/02/08111815/Companies-look-at-corporate social responsibility-initiati.html (accessed 24 December, 2012).

Chi-Shiun Lai, Ettlie, J. E. and A. H. Rubenstein (2010) "Firm size and product innovation." Journal of Product Innovation Management 4(2): pp. 89-108.

Cornell, S. and Shapiro, M. (2007) Understanding the Influence of corporate social responsibility on Corporate Identity, Image, and Firm Performance. Management Decision, Vol. 48, No.10, pp.1469-1492.

Davis, K. (1960) Corporate Social Responsibility and organizational Profitability. J. Econ. Soc. Res. 3(1):113-124.

Dean, D. H. (2008) Consumer perception of corporate donations effects of company reputation for social responsibility and type of donation. Journal of Advertising 32(4): 91-102.

Detomasi, D. A. (2008) The political roots of corporate social responsibility. Journal of Business Ethics, 82, 807-819.

European Foundation for Quality Management (EFQM, 2007) EFQM internal report. http://www.efqm.com.my/aboutdigi/ doc (accessed 22 December, 2012).

Fombrun, T.M (2006) Shareholder value, stakeholder management, and social issues: What's the bottom line?" Strategic Management Journal, 22 (2): 125-139.

Friedman, (2008) The social responsibility of business in to increase its profits. New York Times Magazines, 13 Sept., 32-33.

Frooman, J. D. (1997) "Strategic philanthropy: responding to negative portrayals of corporate social responsibility." Corporate Reputation Review 3(2): 124-136. 
Garriga F. and Mele, S. (2004) Corporate Social responsibility as Risk Management: A model for Multinationals. Social Responsibility Initiative Working Paper, No.10. Cambridge MA. John F. Kennedy School of Government, Harvard University.

Gray, R. and Balmer, D. (1998) Social and Environmental. Disclosure and Corporate Characteristics: A Research note and Extension. Journal of Business Finance and Accounting, 28 (3 \&4), pp.327-356.

Guenster, H., Rettab, E., Brik, P. and Mellahi, T. (2005) Corporate social responsibility - a PR invention?, Corporate Communication. An International Journal, 6 (1), 18-23.

Hamilton, D., Griffin, J.J. and Mahon, J.F. (2003) "The Corporate Social Performance and Corporate Financial Performance Debate: Twenty-Five Years of Incomparable Research." Business and Society. 36: pp 5-31.

Herremans, T., Collier, T., De Man, F. and Kahn, T. (2003) Corporate social responsibility and its impact on corporate reputation, Brand Strategy (Sept), Issue 195, p. 40-41.

Jamali, G. (2006) "Corporate social responsibility: A three-domain approach." Business Ethics Quarterly: 503-530.

Jamali, G. and Mirshak, S. (2007) "The Impact of Product Recalls on the Wealth of Sellers," Journal of Political Economics. 93(3) 512-536.

Jensen, R. A. (2002) Being good while being bad: Social responsibility and the international diversification of U.S. firms. Journal of International Business Studies, 37(6), 850-862.

Jones, D. R. (2005) "The effect of corporate social responsibility on corporate reputation." Journal of Marketing: 16-32.

Litz, R. A. (1996) A resource-based view of the socially responsible firm: Stakeholder interdependence, ethical awareness, and issue of responsiveness as strategic assets. Journal of Business Ethics, 15, 1355-1363.

Lodgson, J. M. and Wood, D. J. (2002) Business citizenship: From individuals to organizations. Business Ethics Quarterly, Ruffin Series, 3, 59-94.

Lohmans, G and Steinholtz, P. (2004) The Boundaries of Strategic Corporate Social Responsibility. Journal of Consumer Marketing, 18,(7), pp 595-630.

Mackey, A., Mackey, T. B., and Barney, J. B. (2007) Corporate social responsibility and firm performance: Investor preferences and corporate strategies. Academy of Management Review, 32(3), 817-835.

Mahon, M. (2002) Social responsibility and impact on society, The TQM Magazine, 12, (3), $172-178$.

Manne, I., O. (2006) A stakeholder model for implementing social responsibility in marketing. European Journal of Marketing 39(9/10): 956-977.

Matten, R. K. and Moon, N. S. (2004) An analysis of linkage between economic value added and corporate social responsibility", Management Decision, 46(9): 1437-1443.

McWilliams, A. and Siegel, D. (2000). Research notes and communications. Corporate social responsibility and financial performance: correlation or misspecification? Strategic Management Journal, 21, pp 603-9.

Miles, D. J. (1987) "Corporate social performance revisited." Academy of management review: 691-718.

Onwuegbuchi, D.K. (2004). "The relationship Between Perceptions of corporate citizenship and Organizational Commitment." Business and society, 43 (3):296-319, Sage Publications.

Porter, R. and Cramer, G. (2002) Social capital in firm-stakeholder networks: A corporate role in community development. Journal of Corporate Citizenship, 26, 121-134. 
Published by European Centre for Research Training and Development UK (www.eajournals.org)

Quazi, E. and O'Brien, T. (2008) Evaluate Corporate Social Responsibility. Disclosure Annual Report Companies in Multifarious Group of Industry Members of Jakarta Stock Exchange, Indonesia. Social Responsibility Journal, 4(3) Emerald Group Publishing Ltd.

Salawu R. O. (2007) "Corporate Social Responsibilities, Nigeria, Onitsha: Africana FEP Limited Evidence from oil companies in Nigeria”. Nig. J. Bus. Soc Sc; 1(1), 31-42.

Secchi, D. (2007) Utilitarian, managerial and relational theories of corporate social responsibility. International Journal of Management Reviews, 9, 4, 347-373.

Shane L. and Spicer D. (1983) "The corporate social-financial performance relationship." Bus. Soc. 36, 419-429

Simpson, W. G. and Kohers, T. (2002) "The Link between Corporate Social and Financial Performance: Evidence from the Banking Industry,” J. Bus. Ethics. 35, 97-109

Singer, J. D. H. (1970) “An empirical examination of the relationship between corporate social responsibility and profitability." Academy of Management Journal, 28 (2): 446-463.

Wartick, A. (1992) Trend performance in credit financing of rural business activities in Nigeria: A case study of community banks in Ibadan, Oyo State. International Journal of Agriculture and Rural Development, 7 (1): 50-60.

Whetten, S.A., and Mackey, B. G. (2002) "The corporation social performance - financial performance Link”. Strategic Management. Journal. 18 (4) 303-319

Williams, T. and Barrett, P. (2000) "Making Corporate Social Responsibility (corporate social responsibility) Operable: How Companies Translate Stakeholder Dialogue into Practice." Business and Society Review, 111 (2), pp 137-163.

Story, E.D and Johnsons S. (1987). "Small and Medium Enterprises and Employment thesis submitted to St. Clements University for Award of Degree of Doctor of Philosophy in Management. 